\title{
ÇOCUK ODAK'SIZ' HABERCILIK: INTERNET GAZETELERINDE ÇOCUK IÇERIKLI HABERLERIN SUNUMU VE ETIK IHLALLER
}

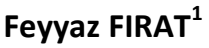

\begin{abstract}
öz
İnternetin haber üretimini ve sunumunu kolaylaștırıcı olanakları internet gazetelerinde basılı gazetelere kıyasla çok daha fazla haber yer almasını sağlamaktadır. Fakat gerek habercilerin daha fazla ve 'anlık' haber sunma kaygısı gerekse yeterli mesleki bilgiye sahip olmamaları, haberin niteliksel/etik unsurlarının ihmal edilmesine sebep olabilmektedir. Bu hatalar, söz konusu çocuk içerikli haberler olduğunda çok daha bariz bir hal almaktadır. Bu araştırmada Türkiye'de en çok okunan internet gazeteleri Hürriyet, Habertürk, Sözcü ve Haberler.com'un çocuk içerikli haberlere ne oranda yer verdikleri ve bu haberlerin sunumunda ne tür etik ihlaller yapıldığını saptamak amaçlanmıştır. Araştırmada niceliksel içerik analizi yöntemi kullanılmıştır. 6-20 Mayıs 2015 tarihleri arasını kapsayan 15 günlük inceleme sonucunda 4 gazetede çocuk içerikli toplam sadece 122 habere rastlanmıştır. Bu da, ülkemiz nüfusunun 3'te 1'lik gibi önemli bir bölümünü oluşturan çocukların, incelenen toplam haberler içinde yer alma oranının yüzde 1,4 gibi düşük bir düzeyde olduğunu göstermektedir. İncelenen 122 haberin yüzde 79'unun Polis/Adliye kategorisinde sunulduğu görülmüştür. Değerlendirilen 122 haberin yüzde 79,5'inde çocukların 'suç odağı' veya 'mağdur' olarak yer alması, çocukların daha çok “olumsuz”, olarak nitelendirilebilecek haberlerin konusu olduğunu göstermektedir. Bu haberlerin yüzde 73'ünde ise çeşitli etik ihlaller bulunmaktadır. Çalışma, çocuk içerikli haberlerin sunumunun internet gazeteleri üzerinden araştırılması bakımından özgündür.
\end{abstract}

Anahtar Kelimeler: İnternet gazeteciliği, çocuk içerikli haberler, çocuk hakları, etik, gizlilik

\section{NON-CENTERED CHILDREN JOURNALISM: PRESENTATION OF CHILDREN THEMED NEWS ON THE ONLINE NEWSPAPERS AND ETHICAL VIOLATIONS}

\begin{abstract}
Internet offers some opportunities in the sense of ease of news production and presentation that there are much more news take place on the online newspapers compare to traditional paper-based newspapers. However, not only concerns of journalists about offering more and instant news, but also lack of enough occupational knowledge can be the reason of ignorance of qualitative/ethical factors of the news. These mistakes, when it is about children themed news, are more obvious. In this study, most read 4 internet newspapers in Turkey that, Hürriyet, Habertürk, Sözcü and Haberler.com to what extent give place to children themed news and what kind of ethical violations are done on the presentation of those news are aimed to analyze. On the research, quantitative content analyze method is used. At the end of 15 days-analyze, covering 6-20 May 2015 dates, it is seen that all of those 4 newspapers have just 122 news about children. This shows that children, with the one out of three population rate in Turkey which is a substantial part of the population, represented on the news with a very low level rate of 1,4 percent. It is found that 79 percent of all those 122 news are analyzed, presented under the category of Police/Justice.79,5 percent of 122 news evaluated shows that children take place on the news as
\end{abstract}

\footnotetext{
${ }^{1}$ Arş. Gör., Gazi Üniversitesi İletişim Fakültesi Gazetecilik Bölümü, feyyazfirat@gazi.edu.tr
} 
'victim' or 'suffered' means they are mostly the subject of 'negative' news. There are various ethical violations 73 percent of these news. This study is the first, in terms of children themed news' presentation analyzed over online newspapers.

Keywords: Internet journalism, children themed news, children rights, ethic, privacy

\section{Giriş}

Gerek dünyada gerekse ülkemizde teknik internet altyapı hizmetlerinin giderek iyileşmesinin yanı sıra internet kullanım oranının artması, kullanıcıların medyaya zaman veya mekân sınırlılığı olmaksızın ulaşmasının da önünü açmıştır. Dizüstü bilgisayarlar, tabletler, akıllı cep telefonları çevrimiçi bir yaşam tarzını da beraberinde getirmiştir. Geçmişte kamu kurumlarına bizzat gidilerek halledebilebilecek işler, bugün 'e-devlet' uygulamasıyla çözülebilmekte, bankacılık işlemleri internet bankacılığı aracılığıyla bankaya gitmeye gerek kalmadan gerçekleştirilebilmektedir. Diğer yandan kullanıcılar günlük gazetelerini de internet üzerinden okuyabilmekte, dolayısıyla bayiye gitme ve ücret ödeme gibi zorunluluklar da ortadan kalkmış olmaktadır. İnternet üzerinden gazete okumayı cazip kılan bu unsurlar, geleneksel basılı gazeteleri internet haberciliği yapma konusunda ikna etmiştir. Bugün gelinen nokta itibariyle ülkemizde 100'e yakın büyük haber sitesi bulunmaktadır (http://www.sanalbasin.com). Elbette internetin haber niceliğine yapmış olduğu katma değer, haberlerin niteliğinin de yüksek olduğu anlamına gelmemelidir. Gazeteler genel olarak incelendiğinde, haberlerde pek çok etik ihlalin olduğu göze çarpacaktır. Özellikle konusu çocuk olan haberler incelendiğinde etik ihlallerin daha belirgin olduğu ortaya çıkmaktadır. Örneğin daha önceki yıllarda Cem Tutar (2011) ve Şule Yüksel Özmen (2012) tarafindan gerçekleştirilen iki farklı araştırmanın bulguları, geleneksel basılı gazetelerin çocuk içerikli haberlerde yapmış olduğu etik ihlallerin boyutlarını gözler önüne sermektedir. Yani, söz konusu durum, kendini savunma ve hakkını gözetme konusunda savunmasız olan çocuklar olduğunda profesyonel gazetecilik kodları bir kenara bırakılabilmektedir.

$\mathrm{Bu}$ noktadan hareketle araştırma, uluslararası internet ölçüm şirketi Gemius'un 2014 Ocak ayı verilerine göre (http://www.connectedvivaki.com), Türkiye'de en çok okunan Hürriyet, Habertürk, Sözcü ve Haberler.com haber 
sitelerinde çocuk içerikli haberlerin sunumunun incelenmesi üzerinedir. $\mathrm{Bu}$ çalışmanın amacı, belirtilen haber sitelerinde çocuk içerikli haberlere ne kadar yer verildiğini ve bu haberlerin ne şekilde sunulduğunu tespit etmektir. Ayrıca çocuğun suçlu veya mağdur olarak yer aldığı haberlerde "kimliğin gizliliği" ilkesine uyulup uyulmadığı araştırılacaktır. Gerek zaman gerekse insan kaynağı sınırlılığından dolayı çalışma söz konusu 4 gazeteyle sınırlandırılmıştır. Araştırma niceliksel içerik analizi yöntemiyle gerçekleştirilmiştir. Bunun için öncelikle bir kodlama cetveli oluşturulmuş, sonrasında kodlama cetvelinde yer alan kategorilerin hatalardan arındırılması için öncü bir analiz yapılarak formun geçerliliği denetlenmiştir.

Çalışma, Goffman'ın çerçeveleme kuramına dayanmaktadır. Goffman'a (1986) göre, haber metinleri, okuyucuların haber konusu olay ve kişiler hakkında nasıl bir anlamlandırma geliştirmeleri isteniyorsa o yönde inşa edilmektedir. Dolayısıyla, haber sunumunda habercilerin kullandığı kavramların ve haberin kendisinin gelişigüzel seçilmediği ileri sürülmektedir. Tankard'a (2001) göre, çerçeveleme teorisi, medyanın, izler kitleyi oluşturan bireylerin düşüncelerine bir referans çerçevesi yerleştirdiğini kabul eder. Bir medya çerçevesi "haber içeriğindeki ana örgütleyici fikirdir, konunun (meselenin) bazı özellik veya unsurlarını seçerek, öne çıkararak, dışlayarak ve ayrıntılı inceleyerek bağlamı verir” (Tankard, 2001: 95). Dolayısıyla, "Medya çerçeveleri sembolleri kullananların sürekli olarak ister görsel olsun ister sözlü olsun söylemi düzenledikleri anlama, yorumlama, sunum, seçme, vurgulama ve dışlama sabit kalıplarıdır” (Nelson vd., 1997a: 7).

Daha ayrıntılı biçimde ifade edilirse, "çerçeveleme temel olarak algılanan gerçekliğin bazı yönlerini seçmek ve onları iletişimsel bir metinde daha görünür hale getirmek böylece ele alınan bir konuya yönelik belirli bir problemi tanımlama, neden ve sonuçlarını yorumlama, ahlaki değerlendirme ve/veya çözüm önerisi sunmaya katkıda bulunmaktır" (Entman, 1993: 52).

Zaman zaman çerçeveleme yaklaşımıyla gündem kurma yaklaşımının birbiriyle karıştırıldı̆̆ 1 ve birbirinin yerine kullanıldı̆̆ını ifade eden Scheufele’e (2004:405) göre, çerçeveleme yaklaşımı en genel düzeyde bireylerin meseleler hakkında nasıl düşüneceklerini belirlerken, gündem kurma yaklaşımı ne konuda düşüneceklerini belirlemektedir. 
Çerçeveleme paradigmasında iki düzeyde çerçeveler ortaya çıkar: Medya çerçeveleri, izleyici çerçeveleri. Haber çerçevesi olarak da adlandırılan medya çerçeveleri, haber sunumunda yer alan ve olaya anlamını veren bir düzenleyici fikir veya öykü akışı olarak tanımlanmışlardır (Gamson ve Modigliani, 1989: 2). Bu çerçeveler, habercilik alanında herhangi bir olay sunulurken, izleyici/okuyucunun söz konusu olayı belli bir biçimde algılamasını ve olayla ilgili belli bir biçimde düşünmesini sağlayan sunum biçimleridir (Kılıç, 2011: 5).

Araştırma, çocuk içerikli haberlerin internet haber sitelerindeki sunumunu inceleyen ilk çalışma olması bakımından önemlidir. Araştırma kapsamında, söz konusu haber sitelerinde 6-20 Mayıs 2015 tarihleri arasında 15 günlük süreçte yayınlanan çocuk içerikli haberler incelenmiştir. Analiz saati olarak ise 17.00-20.00 saatleri arası dikkate alınmıştır.

Araştırmada yanıt aranan sorular şöyle sıralanabilir:

1. İncelenen gazetelerde, çocuğun suçlu ve/veya mağdur olarak yer aldığı haberlerde kimliğin gizliliği ilkesine uyma oranı nedir?

2. İncelen haberler göz önünde bulundurulduğunda çocukların konu olduğu "olumsuz" haberlerin ve "olumlu" haberlerin dağılımı nedir?

3. İncelenen gazetelerde, çocuk içerikli haber sayısının gazetelerin ana sayfalarındaki toplam haber sayısına oranı nedir?

$\mathrm{Bu}$ çalışmada, incelenen haber sitelerinde çocuk içerikli haberlerin çoğunun sunumunda etik ihlallerin bulunduğu varsayımından hareket edilmiştir.

\section{Yasalar önünde 'çocuk'}

Ülkemizde, çocukluğun başlangıcı Türk Medeni Kanunu'nda düzenlenmiştir. Buna göre, "Çocuk hak ehliyetini, ana rahmine düştüğü andan başlayarak elde eder", (m.28/2). Çocukluk döneminin süresi konusunda ülkeler arasında hukuki ihtilaflar görülmekle birlikte, batı ülkeleri ve ülkemiz çocukluğu 18 yaşına kadar olan dönem olarak tanımlamaktadır.

18 yaşını doldurmamış bireyler olarak çocuklar, yasalar önünde tam olarak yetişkin sayılabilecekleri zamana kadar hukukta daha spesifik olarak ele 
alınmaktadır. Örneğin, Çocuk Haklarına Dair Sözleşme çocukların korunmasına yönelik olarak hazırlanmış ve üzerinde uzlaşılmış ilkelerden oluşmaktadır. Çocuk Haklarına Dair Sözleşme Birleşmiş Milletlere bağlı ve sivil toplum kuruluşlarıyla birlikte 10 yıllık bir sürede oluşturulmuştur. 20 Kasım 1989'da Birleşmiş Milletlerin 44. Genel Kurulu'nda oy birliği ile kabul edilmiştir. Sözleşme ABD ve Somali dışında 193 ülke tarafından onaylanmıştır. Türkiye ise bu sözleşmeyi 14 Eylül 1990’da imzalamıştır. Yine İnsan Hakları Evrensel Bildirgesi çocuğun uluslararası bağlamda ortak bir şekilde ele alınıp, haklarının ifade edildiği sözleşmelerdendir.

Çocuk Haklarına Dair Sözleşme'de çocuğun yararının üstün tutulması ilkesi bu noktada ele alınabilir. Buna göre, çocuğun menfaatlerinin toplumsal veya bireysel başka menfaatlerle çakışması durumunda, çocuğun menfaatine öncelik tanınmasını ifade eder. Literatürde bu durum 'ç̧ocuğun yüksek yararı", “çocuk yararının önceliği şeklinde"” tanımlanmaktadır (Erdoğan, 2011:196).

Çocuk Haklarına Dair Sözleşme’nin 12. Maddesinde “'görüşlerini oluşturma yeteneğine sahip çocuğun kendini ilgilendiren her konuda görüşlerini serbestçe ifade etme hakk1" ve "çocuğu etkileyen bir kovuşturmada çocuğun doğrudan veya temsilcisi aracılığı ile dinlenilmesi hakkı' 'ndan söz edilmektedir. Bu da 'çocuğun görüşlerinin alınması' ilkesi olarak sözleşmede yer almaktadır.

Çocuğun cinsel istismarı da uluslararası hukuki anlaşmalarla düzenlenip tanımlanmış olan unsurlardır. Yine Çocuk Haklarına Dair Sözleşme’ye göre, “Taraf devletler, çocuğu, her türlü cinsel sömürüye ve cinsel suistimale karşı koruma güvencesi verirler. Bu amaçla taraf devletler özellikle: a) Çocuğun yasadışı bir cinsel faaliyete girişmek üzere kandırılması veya zorlanmasını; b) Çocukların, fuhuş ya da diğer yasadışı cinsel faaliyette bulundurularak sömürülmesini; c) Çocukların pornografik nitelikli gösterilerde ve malzemede kullanılarak sömürülmesini önlemek amacıyla ulusal düzeyde ve ikili ile çok taraflı ilişkilerde gerekli her türlü önlemi alırlar'’(m.34).

Buraya kadar ele alınan konular, çocuğun yasalar tarafından korunmaya ve güvence altına alınmaya çalışıldığının göstergesidir. Ancak günümüzdeki mevcut durum göz önünde bulundurulduğunda ise dünya üzerinde hala milyonlarca çocuğun 
fiziksel, psikolojik ve cinsel anlamda istismar edildiği görülmektedir. Söz gelimi medyada 18 yaşından küçük suç faillerinin ve mağdurlarının kimliklerinin açıklanması yasağı (Basın K. M. 21) bu alanda yetersiz kalmaktadır. Kaldı ki medyada yer alan haberler incelendiğinde bu yasağın yetersizliği çok daha net görülecektir.

\section{2. Çocuk, medya ve etik}

Birleşmiş Milletler Çocuk Hakları Sözleşmesi'ne göre çocuklar, 18 yaşın altındakiler olarak tanımlamaktadır (ÇHS, 1990). Daha önce ifade edildiği gibi ülkemizde de 18 yaşına kadar olan bireyler çocuk olarak kabul edilmekte ve bu kişiler yasalar önünde çocuklara özgü kanunlara göre ele alınmaktadır.

2014 TÜİK (Türkiye İstatistik Kurumu) verilerine göre Türkiye'de yaklaşık 23 milyon çocuk bulunmaktadır (http://www.tuik.gov.tr.). Bu da 80 milyonluk ülke nüfusunun yaklaşık üçte birinin çocuklardan oluştuğu anlamına gelmektedir. Dolayısıyla gerek sosyal hayatta gerekse medyada çocukların göz ardı edilmesi mümkün görünmemektedir. Ancak, ülkemiz medyası göz önünde bulundurulduğunda çocukların medyada eksik temsil edildiği ve çok az yer aldığ 1 görülmektedir. Bu noktada Şule Yüksel Özmen, 2012 yılında gerçekleştirmiş olduğu "Çocuğun Adı Yok: Televizyon Haberlerinde Çocuğun Sunumu ve Çocuk Hakları Bağlamında Değerlendirilmesi” konulu çalışmasında haberlerde çocuğun nasıl yer aldığını incelemiş ve daha çok “olumsuz”' bir sunumla temsil edilmelerinin yanı sıra medyada çok az yer aldıklarını tespit etmiştir. Diğer yandan Cem Tutar 2011 yılında gerçekleştirmiş olduğu "Yazılı Basında Çocuk Haklarının Temsili: Hürriyet, Cumhuriyet, Sabah ve Zaman Gazeteleri Üzerinde Yapılan Bir Araştırma', adlı çalışmasında 15 günlük süre içerisinde 4 gazetede çocuk içerikli sadece 96 haber olduğunu ve bunların çok sınırlı bir alanda sunulduğunu ifade etmektedir. Sevda Alankuş'un (2007) çocukların medyada yeterince yer almamasıyla ilgili yapmış olduğu “eksik yurttaşlar” tanımı da bu noktada oldukça anlamlı görünmektedir.

Alankuş'un (2007: 28) Uluslararası Gazeteciler Federasyonu'nun (FIJ) raporuna göre yaptığı değerlendirmede, çocuklar dünya nüfusunun üçte ikisinden fazlasını oluşturdukları halde, medyanın kapsadığı konuların yüzde beşinden azı 
çocuklarla ilgilidir. Medya çocukları haber konusu yaptığında ise, bu 'ç̧ocuk fuhuşu, organ kaçakçılı̆̆ı, cinsel istismar, eğitim ve sağlık hizmetlerinden mahrum bırakılmaları, çocuk emeği sömürüsü, sokak çocukları, yakınları tarafından cinsel taciz, babanın ya da öğretmenin cinsel tacizi” gibi konularda olmaktadır (Alankuş, 2007: 28). Medyada çocuklara çok az yer verilmesi ve yer verildiğinde "olumsuz örneklerle"' sunulması dışında en önemli problemlerden biri de haber sunumlarında habercilerin etik ilkeleri ihlal etmesidir. Örneğin, Gazetecilerin Hakları ve Yükümlülüklerine İlişkin Uluslararası Deklarasyon'da belirtilen "mahremiyete saygı" ilkesi de çocuk içerikli haberlerde sıklıkla göz ardı edilmektedir (UNESCO, 2015: 49).

Etik, insan davranışlarını ahlakilik kuralları içinde araştıran ahlak bilimi anlamına gelmektedir (Uzun, 2007: 11). Gazetecilik söz konusu olduğunda gazetecilik ahlakı, meslek ilkeleri, davranış kodları, gazetecilik deontolojisi ve gazetecilik etik kuralları gibi adlarla anılan kodlar, mesleği düzenleyen davranış kurallarına işaret etmektedir (Uzun, 2007: 12). Belsey ve Chadwick'e (2011) göre gazetecilik davranış kodları, gazetecinin araştırdığı ve hikâyeye konu olan kişilerin korunmasını sağlar. Bunlar için bir kodda gazetecinin hakkında yazdığı kişi veya kişilerin mahremiyetine girmemesi, taciz etmemesi istenebilir (Belsey ve Chadwick, 2011: 91). Girgin'e (2008: 240) göre etik, “görece özgür biçimde çalışan gazetecilerin, artan çeşitli baskılara rağmen kendilerini ve mesleklerini korumak, okurun güvenini kazanmak amacıyla uymaya söz verdikleri kurallar" olarak ortaya çıkmıştır. Elbette gazetecinin değer yargıları da bu noktada önem kazanmaktadır. Çünkü medyada neyin haber olacağı, nasıl anlatılacağı ve yorumlanacağı tamamen gazetecinin değer yargıları tarafından belirlenmektedir (Çaplı, 2002: 81). Haberlerde görülen etik ihlallerin ardalanında yatan temel sebeplerden birinin bu olduğu söylenebilir. Örneğin, çocuğun "suçlu”, ve “mağdur”, olarak yer aldığı haberlerde çocuğun kimliğinin hiçbir şekilde teşhir edilmemesi gerektiği genel kabul görmüş etik kodlardan biridir. Fakat az önce de belirtildiği gibi gazetecinin haberi değer yargılarıyla birlikte ele alması, birtakım etik ilkelerin ihlal edilmesini de beraberinde getirmekte ve dolayısıyla gerek haber konusu çocuğun gerekse ailesinin maddi ve manevi onarılamaz bir yıkımla karşı karşıya kalmasına sebep olmaktadır. 


\section{3. Çocuk odaklı habercilik anlayışı}

Çocuk odaklı habercilik, çocuklara ilişkin yasalarda, uluslararası sözleşmelerde belirtilen haklarının haber yazım ve sunum sürecinde göz önünde bulundurulması anlamına gelmektedir. İlk bölümde de ifade edildiği gibi çocuğun hukuk önünde sahip olduğu birtakım haklar bulunmaktadır. Bu haklardan bazıları haber konusu yapılan çocuğun sunumu ve kimliğinin gizlenmesinin gerekliliğine ilişkindir.

Genel olarak çocuklarla ilgili haberlerin sunumunda gazetecinin uyması gereken birkaç önemli kural şöyle sıralanabilir. İlk olarak gazeteciliğin temel gerekleri arasında haberin sade bir dille, doğru, açık ve kesin bir dille verilmesi gerekir (Tokgöz, 2012: 144). Her türlü yorum ve değerlendirme haberin dişından tutulmalıdır. Yani muhabir, haberi yazarken habere müdahil olmamalı olanı anlatmalıdır. İkinci olarak sunulan haberler kesin ve açık olmalıdır. Zira izleyicileri/okuyucuların inanmalarını sağlamak bakımından kesinlik son derece önemlidir (Tokgöz, 2012: 146). Son olarak ve en önemlisi haberin doğru olması gerekmektedir. Doğru olmayan bir haber gazetenin itibarına zarar vereceği gibi haberi yazan gazeteci hakkında da -özellikle haberde birtakım ithamlar ve etik ihlaller varsa- suç duyurusu açılmasına sebep olacaktır.

Haber kuruluşlarının çoğunun kabul ettiği çocuk koruma politikalarında, çocukların kimliklerinin ortaya çıkması, gençlerin özel yaşamlarına saygı gösterilmesi ve bakım altındaki çocukların isimlerinin kullanılmasının yasaklanması konularında rehber ilkeler bulunmaktadır (Unicef, 2007: 72). Fakat belirtilmelidir ki, her ne kadar medya kuruluşları bir takım rehber ilkelere sahip olsalar da, bu ilkelere tam olarak uyulduğunu söylemek güçtür. Özellikle medyamızda çocuk içerikli haberlerin sunumunda görülen etik ihlaller bunun kanıtı olabilir.

\section{Araştırma bulguları}

Araştırma kapsamında Gemius uluslararası internet ölçüm şirketinin 2014 Ocak ayı verilerine göre ülkemizde en fazla okunan internet gazeteleri Hürriyet, Habertürk, Sözcü ve Haberler.com'da çocuk içerikli haberlerin sunumu incelenmiştir. $\mathrm{Bu}$ haber siteleri 6-20 Mayıs tarihleri arasında 15 gün boyunca 
taranmıştır. İçerik analizi yöntemiyle gerçekleştirilen araştırmada elde edilen veriler SPSS programında analiz edilerek aşağıda tablolar halinde sunulmuştur. İncelenen gazetelerin sadece ana sayfaları taranmış, diğer sayfaları ise araştırma dışında tutulmuştur.

Araştırma sonucunda 4 gazetede, çocuk içerikli toplam 122 habere rastlanmıştır. Tablo 1, çocuk içerikli haberlerin sayfanın hangi bölümünde yer aldığını göstermektedir.

Tablo 1. Haberin Sayfadaki Konumu

\begin{tabular}{|l|c|c|}
\hline & Sayı & Yüzde (\%) \\
\hline Manşet & 28 & 23 \\
\hline Manşet Üstü Kutu & 2 & 1,6 \\
\hline Manşet Yanı Kutu & 2 & 1,6 \\
\hline Manşet Altı Kutu & 1 & 0,8 \\
\hline Diğer & 89 & 73 \\
\hline Toplam & 122 & 100 \\
\hline
\end{tabular}

Buna göre, incelenen çocuk içerikli haberlerin yüzde 23 'ü manşetten sunulmuştur. Manşet üstü, altı ve yanında yer alan haberlerin toplam yüzdesinin ise yüzde 5'ten az olduğu görülmektedir. Tabloda “'Diğer", olarak ifade edilen kısım ise sayfanın en alt bölümlerinde yer alan ve okuyucuların dikkatini çekme şansı daha az olan haberlerin yer aldığı alanlar olarak kabul edilmiştir. Buna göre incelenen çocuk içerikli haberlerin yüzde 73'ü haber sitesinin en alt, dolayısıyla en az görünür olan bölümlerinde küçük bir alan içinde yer aldığı tespit edilmiştir. Kısaca belirtmek gerekirse incelenen sitelerdeki çocuk içerikli haberlerin yüzde 73'ü sayfaların editörleri tarafından "önemsiz" olarak kabul edilmiştir.

Tablo 2. Konularına Göre Haber Kategorileri

\begin{tabular}{|l|c|c|}
\hline & Sayı & Yüzde (\%) \\
\hline Siyasi & 8 & 6,6 \\
\hline Ekonomi & 2 & 1,6 \\
\hline Magazin & 12 & 9,8 \\
\hline Polis/Adliye & 79 & 64,8 \\
\hline Sağlık & 7 & 5,7 \\
\hline Bilim/Teknoloji & 5 & 4,1 \\
\hline Kategori Yok & 9 & 7,4 \\
\hline
\end{tabular}


Tablo 2 ise incelenen çocuk içerikli haberlerin hangi haber kategorileri bağlamında sunulduğunu göstermektedir. Buna göre söz konusu dört gazetede yer alan çocuk içerikli haberlerin yüzde 64,8'i Polis/Adliye kategorisine aittir. En yüksek yüzdenin bu kategoriye ait olması, haberlerde çocukların daha çok suçlu ve/veya mağdur olarak yer aldıklarının bir göstergesi olarak da kabul edilebilir.

Tablo 3. Habere Konu Çocuğun Cinsiyeti

\begin{tabular}{|l|c|c|}
\hline \multicolumn{1}{|c|}{ Cinsiyet } & Sayı & Yüzde (\%) \\
\hline Kız & 55 & 45,1 \\
\hline Erkek & 56 & 45,9 \\
\hline Belirtilmemiş & 11 & 9 \\
\hline Toplam & 122 & 100 \\
\hline
\end{tabular}

Tablo 3, incelenen çocuk içerikli haberlerde yer alan çocuğun cinsiyetini göstermektedir. Tablo analiz edildiğinde bu haberlerde yer alan kız ve erkek çocuk sayısının görece dengeli olduğu söylenebilir. Buna göre 122 haberin 56's1 kız çocuklarıyla, 55'i ise erkek çocuklarıyla ilgilidir.

Tablo 4. Habere Konu Çocuğun Durumu

\begin{tabular}{|l|c|c|}
\hline & Sayı & Yüzde (\%) \\
\hline Fiziksel Şiddet Mağduru & 29 & 23,8 \\
\hline Cinsel İstismar & 19 & 15,6 \\
\hline Fiziksel Şiddet + Cinsel İstismar & 3 & 2,5 \\
\hline Ekonomik Açıdan Mağdur & 14 & 11,5 \\
\hline Başarı konusu & 13 & 10,7 \\
\hline Reklam Aracı & 6 & 4,9 \\
\hline Terkedilme/Evlatlık & 3 & 2,5 \\
\hline Suç Odağı & 8 & 6,6 \\
\hline Diğer & 27 & 22,1 \\
\hline Toplam & 122 & 100 \\
\hline
\end{tabular}

Tablo 4, çocuk içerikli haberlerde sunulan çocuğun durumunu göstermektedir. $\mathrm{Bu}$ haberlerin yüzde 23,8'inde çocuklar fiziksel şiddet mağduru olarak, yüzde 15,6'sında cinsel istismar mağduru, yüzde 2,5'inde ise hem fiziksel hem de cinsel istismar mağduru olarak sunulmuştur. Çocukların ekonomik açıdan mağdur olarak sunulduğu haberlerin oranı yüzde 11,5'tir. Haberlerin yüzde 6,6'sında ise çocuklar suç odağı olarak sunulmuştur. Çocukların başarı konusu olarak sunulduğu haberlerin oranı ise sadece yüzde 10'dur. Tablo genel olarak 
değerlendirildiğinde incelenen haberlerin yaklaşık yüzde 70'inde çocuklar mağdur veya suçlu olarak yer aldığı söylenebilir.

Tablo 5. Haber Konusu Çocuğun Sunumu

\begin{tabular}{|l|c|c|}
\hline & Sayı & Yüzde (\%) \\
\hline Öğrenci & 45 & 36,9 \\
\hline Suçlu & 8 & 6,6 \\
\hline Çocuk Gelin & 6 & 4,9 \\
\hline Hasta/Özürlü & 5 & 4,1 \\
\hline Yaşamını Yitirmiş & 20 & 16,4 \\
\hline Diğer & 38 & 31,1 \\
\hline Toplam & 122 & 100 \\
\hline
\end{tabular}

Tablo 5. haber konusu çocuğun ne şekilde sunulduğunu göstermektedir. Buna göre incelenen haberlerin yüzde 36,9'unda (45 haber) çocuklar öğrenci olarak sunulmuştur. Yüzde 16,4'ünde yaşamını yitirmiş olarak, yüzde 6,6'sında ise suçlu olarak sunulmuştur.

Tablo 6. Haberde Etik İhlalin Yeri

\begin{tabular}{|l|c|c|}
\hline & Sayı & Yüzde (\%) \\
\hline Yalnızca Metinde & 22 & 18 \\
\hline Metin+Fotoğrafta & 29 & 23,8 \\
\hline Yalnızca Fotoğrafta & 17 & 13,9 \\
\hline Videoda & 9 & 7,4 \\
\hline Video+Metinde & 8 & 6,6 \\
\hline Video+Metin+Fotoğrafta & 4 & 3,3 \\
\hline Etik Dışı Unsur Yok & 33 & 27 \\
\hline Toplam & 122 & 100,0 \\
\hline
\end{tabular}

Tablo 6, incelenen haberlerdeki etik ihlallerin haberin hangi unsurlarında yapıldığını göstermektedir. Buna göre incelenen 4 gazetede yer alan çocuk içerikli haberlerin yüzde 27'isinde etik ihlal bulunmamaktadır. Diğer bir deyişle ise bu haberlerin yüzde 77 'sinde etik ihlaller bulunmaktadır. Bu ihlallerin yüzde 18 'i yalnızca metinde, yüzde 23,8 'i hem metinde hem de fotoğrafta, yüzde 13,9 'u ise yalnızca fotoğrafta gerçekleşmiştir. Çocuklarla ilgili haberlerin sunumunda videoda, metinde, fotoğrafta veya metinde en az birinde her zaman etik ihlalinin görülmüş olması ise dikkat çekicidir. 
Tablo 7. Habere Konu Çocuğun Kimliğinin Teşhir Edildiği Yer

\begin{tabular}{|l|c|c|}
\hline & Sayı & Yüzde (\%) \\
\hline Metinde & 21 & 17,2 \\
\hline Fotoğrafta & 20 & 16,4 \\
\hline Videoda & 12 & 9,8 \\
\hline Birden Fazla Unsurda & 40 & 32,8 \\
\hline Teşhir Edilmemiş & 28 & 23 \\
\hline Toplam & 122 & 100 \\
\hline
\end{tabular}

Tablo 7 incelendiğinde çocuk içerikli haberlerin yüzde 23'ünde çocuğun kimliğinin teşhir edilmediği görülmektedir. Dolayısıyla bu haberlerin yüzde 77'sinde ise çocuğun kimliği bir veya birden fazla unsurda teşhir edilmiştir. Hemen belirtilmelidir ki tablo, çocuğun suçlu veya mağdur olarak yer aldığı haberler göz önünde bulundurularak hazırlanmıştr. Söz gelimi çocuğun başarı unsuru olarak ele alındığı haberlerde kimliğin açıklanması herhangi bir sakınca doğurmayacağı için kodlama formunda rakam olarak sıfır kodlanmıştır. Tabloya göre incelenen haberlerin yüzde 32 'sinde çocuğun kimliği birden fazla unsurda teşhir edilmiştir.

Tablo 8. Gazetenin Haberi Ele Alış Biçimi

\begin{tabular}{|l|c|c|}
\hline & Sayı & Yüzde (\%) \\
\hline Yanlı & 56 & 45,9 \\
\hline Yansız & 66 & 54,1 \\
\hline Toplam & 122 & 100,0 \\
\hline
\end{tabular}

Tablo 8, çocuk içerikli haberlerin incelenen gazetelerde ne şekilde ele alındığını göstermektedir. Buna göre incelenen 122 haberin yüzde 54,1'i tarafsız olarak sunulmuştur. Haberlerin yanlı veya yansız olduğu değerlendirilirken haber başlığı, haber spotu ve metni değerlendirilmiştir. Haberde yorum ve/veya değerlendirme içeren sıfatlara rastlanması durumunda haber "yanlı" olarak kodlanmıştır.

Tablo 9. Haberin İçeriği

\begin{tabular}{|l|c|c|}
\hline & Sayı & Yüzde (\%) \\
\hline Olumlu & 20 & 16,4 \\
\hline Olumsuz & 97 & 79,5 \\
\hline Nötr & 5 & 4,1 \\
\hline
\end{tabular}




\begin{tabular}{|l|c|c|}
\hline Toplam & 122 & 100,0 \\
\hline
\end{tabular}

Tablo 9, incelenen haberlerdeki çocukların daha çok “olumlu” örnekler mi, “olumsuz”' örneklerle mi sunulduğuna ilişkin verileri sunmaktadır. Çocuğun konu olduğu haberler Polis/Adliye haberleri olduğunda kodlama formunda olumsuz, çocuk başarı konusu olarak sunulduğunda ise haber olumlu olarak değerlendirilmiştir. Buna göre, incelenen 122 haberin yüzde 79,5'inde çocuklar haberlerde olumsuz örneklerle sunulmaktadır. Diğer yandan bu tablo, çocuğun daha çok olumsuz olaylar söz konusu olduğunda internet haber sitelerinde yer aldığını göstermektedir. Olumlu olaylarla yer aldığı haberlerin oranı ise yüzde 16,4 olarak tespit edilmiştir.

Tablo 10. Çocuk İçerikli Haberlerin Oranı

\begin{tabular}{|c|c|}
\hline 15 Günlük Toplam Haber Sayısı & 8261 \\
\hline Çocuk İçerikli Haber Sayısı & 122 \\
\hline Çocuk İçerikli Haberlerin Oranı (\%) & 1,4 \\
\hline
\end{tabular}

Tablo 10, incelenen 4 haber sitesinin 15 günlük süreçte ana sayfalarında yer alan toplam haber sayısını ve bu haberlerin ne kadarının çocuk içerikli haberler olduğunu göstermektedir. Bu da, toplam haberler içindeki çocuk içerikli haberlerin oranının yüzde 1,4 olduğunu göstermektedir. İlk bölümde bahsedilen çalışmaların bulgularında ise bu oranın yüzde 1,5 ve yüzde 1,7 olduğu belirtilmelidir. Dolayısıyla daha önce bu noktada gerçekleştirilmiş çalışmalar da bulguyu destekler niteliktedir.

Fakat burada ilginç olan nokta ise daha önceki çalışmaların geleneksel basılı gazeteler üzerinden, bu çalışmanın ise internet haber sitelerinden gerçekleştirilmiş olmasıdır. Zira internet haber siteleri geleneksel haber sitelerine göre çok daha fazla haber sunma imkânına sahip olmasına rağmen, yukarıda belirtilen oranlar arasında görüldüğü gibi çok az bir fark vardır. $\mathrm{Bu}$ da, internet haber sitelerinin, basılı gazetelere göre çok daha fazla haber sunma olanağına sahip olmasının çocuk içerikli haber sayısında bir artış sağlamadığını göstermektedir.

\section{Sonuç ve öneriler}

İncelenen çocuk içerikli haberlerin sunumu göz önünde bulundurulduğunda, söz konusu gazetelerin bu haberlere belirli bir bakış açısıyla yaklaşarak, çerçevelediği tespit edilmiştir. Örneğin incelenen haberlerin yüzde 64,8'inin 
Polis/Adliye haberi olması, incelenen gazetelerin çocukları suçlu ve/veya mağdur bireyler olarak çerçevelediğinin en önemli göstergelerinden biri olarak kabul edilebilir. Daha önce, çerçevelemenin, temel olarak algılanan gerçekliğin bazı yönlerini seçmek ve onları iletişimsel bir metinde daha görünür hale getirmek böylece ele alınan bir konuya yönelik belirli bir problemi tanımlama, neden ve sonuçlarını yorumlama, ahlaki değerlendirme ve/veya çözüm önerisi sunmaya katkıda bulunmak olduğu ifade edilmişti. Elde edilen bulgular incelendiğinde, gerçekten de, çocuk içerikli haberlerde olayların belirli yönlerinin ön plana çıkarılarak -mağdur çocuk, suçlu çocuk, çocuk gelin vs.- okuyucuda/izleyicide acıma hissini harekete geçirmeye yönelik bir haber metni üretiminin gerçekleştirildiği görülmektedir. Dolayısıyla, incelenen haberleri üreten gazetecilerin, çocuk içerikli haberleri içerik olarak 'olumsuz/negatif' bir bağlamda çerçeveleyerek sunmayı tercih ettiği görülmektedir. Bu noktada, gazetecilerin neden çocukları olumsuz olayların konusu olarak ele alma konusunda bu denli 'arzulu' olduğu sorusuna cevap aramak anlamlı olabilir. Şayet bu durumun sebebi okunmatıklanma kaygısıysa, kuşkusuz çocuklarla ilgili olumlu haberlerin de haber değeri taşıdığı bilinmelidir.

Ayrıca çocuğun kimliğinin çeşitli şekillerde teşhir edilmesi, çocuğun hayatı boyunca onarılamaz psikolojik ve sosyolojik problemlerle karşı karşıya kalmasına neden olacaktır. Genel olarak bulgular, internet gazetelerinde sunulan çocuk içerikli haberlerde ciddi etik ihlaller olduğunu göstermekte ve dolayısıyla internet haber sitelerinde hukuki denetime yönelik yaptırımlara ihtiyaç olduğu anlaşılmaktadır. Ayrıca, çocuk içerikli haberlerin sunumunda yapılan hatalar internet gazetelerinde "profesyonel gazetecilik" anlayışının yerleşmediğini açıkça göstermektedir.

Diğer yandan, 15 günlük sürede 4 gazetede toplam sadece 122 haberin yer alması, 20 milyonu aşan çocuk nüfusuyla ülkemizde çocukların internet medyasında yeterince temsil edilmediğini gösteren önemli bir sonuçtur. Şule Yüksel Özmen (2012) ve Cem Tutar (2011) tarafından gerçekleştirilmiş olan araştırmalarda da çocuk içerikli haberlerin oranının günlük bir gazetede yüzde 2'yi bile bulmadığını ortaya koymuştur. $\mathrm{Bu}$ sonuca dayanarak, çocuk içerikli haberlerin internet gazetelerinde çok az yer almasının sebebi olarak; (1) genel olarak haberlerin hedef 
kitlesinin yetişkinler olduğu göz önünde bulundurulursa, yetişkinlerin bu haberlere çok fazla ilgi göstermemesi, yani bu haberlerin çok fazla tıklanmaması olabilir. Dolayısıyla editörler, internet gazetelerinde çocuk içerikli haberlere bu yüzden çok fazla yer vermiyor olabilir; (2) çocuk içerikli haberlerin daha çok olumsuz içeriklerle sunuluyor olması ise, habere konu çocuğun ancak 'mağdur' ve/veya 'zavallı' olarak sunulduğu zaman daha çok okunmasıyla ilgili olabilir. Gelecekte yapılacak çalışmalarda, çocuk içerikli haberlerin neden gazetelerde çok az yer aldığı ve neden olumsuz bir içerikle sunulduğuna yönelik derinlikli bir araştırma alana önemli bir katk1 sağlayabilir.

1)Site: [ ]

$\begin{array}{lll}\text { 1. Hürriyet 2. Habertürk } \quad \text { 3. Sözcü 4. Haberler } & \end{array}$

\section{KODLAMA FORMU}

2) Haberin yeri: [ ]

$\begin{array}{llllll}\text { 1. Sürmanşet } & \text { 2. Manşet } & \text { 3. Manşet üstü kutu } & \text { 4. Manşet yanı kutu } & \text { 5. Manşet altı kutu } & 6 \text {. Diğer }\end{array}$

3)Haber türü: [ ]

1.Rutin Haber 2. Röportaj 3 3. Özel Haber $\quad$ 4. Reklam içerikli haber (Advertorial) 5. Video Haber

4) Haberin sunumu: [ ]

$\begin{array}{lllll}\text { 1.Yalnızca Metin 2.Metin+haber foto } & \text { 3. Galeri } & \text { 4.Video } & \text { 5. Video+metin } & \text { 6. Çoklu medya }\end{array}$

5)Haber kategorisi: [ ]

1.Siyasi 2.Ekonomi 3. Magazin 4.Spor 5. Polis/Adliye 6. Sağlık 7. Bilim/teknoloji 8.Kategori yok

6)Haber konusu çocuğun cinsiyeti: [ ]

1. Kız 2. Erkek 3.Belirtilmemiş

7)Haber konusu çocuğun durumu: [ ]

1. Fiziksel şiddet mağduru 2. Cinsel istismar 3. Fiziksel şiddet+Cinsel istismar

4.Ekonomik açıdan mağdur 5.Başarı konusu 6.Reklam aracı 7.Terk edilme/evlatlık 8. Suç odağı 9.Diğer

8)Haber konusu çocuğun sunumu: [ ]

1. Öğrenci 2.Suçlu 3.Çocuk gelin 4. Hasta/Özürlü 5.Yaşamını yitirmiş 6.Diğer

9) Haberde etik ihlal: [ ]

1.Yalnızca Metinde 2.Metin+fotoğrafta 3. Yalnızca Fotoğrafta 4.Videoda 5. Video+metinde 6. Video+Metin+Fotoğrafta 7. Etik dışı unsur yok

10)Çocuğun kimliğinin teşhiri: [ ]

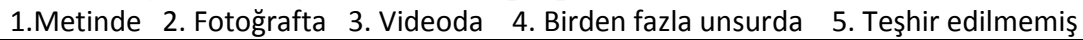

11) Çocukla ilgili teşhir edilen bilgiler: [ ] ]

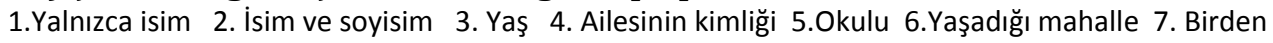
fazla unsur 8.Diğer

12) Gazetenin haberi ele alış biçimi: [ ] ]

1.Yanlı 2.Yansız 


\section{KAYNAKLAR}

ALANKUŞ, Sevda (2007). Çocuk Odaklı Habercilik, İstanbul: IPS İletişim Vakfi Yayınları.

ATABEK, Necdet; UZTUĞ, Ferruh (1998). 'Haberlerde Çerçeveleme ve Öne Çıkarma', Kurgu Dergisi, 15.

BİLGİN, Nuri (2014). Sosyal Bilimlerde İçerik Analizi, (3.Baskı), Ankara: Siyasal Kitabevi.

BELSEY, Andrew and CHADWICK, Ruth (2011). Medya ve Gazetecilikte Etik Sorunlar, (2. Baskı), Çev. Nurçay Türkoğlu), İstanbul: Ayrıntı Yayınları.

ÇAPLI, Bülent (2002). Medya ve Etik, Ankara: İmge Kitabevi.

ENTMAN, Robert M. (1993). 'Framing: Toward Clarification of a Fractured Paradigm', Journal of Communication, 43 (4).

ERDOĞAN, Oktay (2011). Çocuk Hakları, İstanbul: Acar Basım.

GAMSON, William A.; MODIGLIANI, Andre (1989). 'Media Discourse and Public Opinion on Nuclear Power: A Constructionist Approach', The American Journal of Sociology.

GİRGİN, Atilla (2008). Gazeteciliğin Temel İlkeleri, İstanbul: Der Yayınları.

GOFFMAN, Erving (1986). An Essay On The Organization of Experience Frame Analysis, Boston: Northeastern University Press.

KILIÇ, Seyfi (2011). 'Tekel Eylemi Haberlerinde Çerçeveleme: Türk Yazılı Basın Örneği’, İletişim Kuram ve Araştırma Dergisi, 32. 
NELSON, Thomas E.; CLAWSON, Rosalee A., OXLEY, Zoe M. (1997 a). 'Media Framing of a Civil Liberties Conflict and its Effect on Tolerance', The American Political Science Review, September, 91 (3).

ÖZMEN, Şule (2012). “Çocuğun Adı Yok: Televizyon Haberlerinde Çocuğun Sunumu ve Çocuk Hakları Bağlamında Değerlendirilmesi’, İletişim Kuram ve Araştırma Dergisi, 34.

SCHEUFELE, Bertram (2004). 'Framing-Effects Approach: A Theoretical And Methodological Critique', Communications, 29.

TANKARD, James W. (2001). The Empirical Approach to the Study of Media Framing, Reese, Stephen D. vd. (eds), Framing Public Life Perspectives on Media and Our Understanding of the Social World, London: Lawrence Erlbaum Associates.

TÜRKIYY İSTATİSTİK KURUMU, http://www.tuik.gov.tr/PreHaberBultenleri.do? id=18622 , Erişim Tarihi: 19.02.2016.

TUTAR, Cem (2014). "Yazılı Basında Çocuk Haklarının Temsili: Hürriyet, Cumhuriyet, Sabah Ve Zaman Gazeteleri Üzerinde Yapılan Bir Araştırma’, Journal of Yasar University, Say1 34.

TOKGÖZ, Oya (2012). Temel Gazetecilik, Ankara: İmge Kitabevi.

UNESCO (2015). Freedom of Expression and Public Order, Tunisia: United Nations Educational, Scientific and Cultural Organization.

UNICEF (2007). Çocuk Hakları ve Gazetecilik Uygulamaları, Ankara.

UZUN, Ruhdan (2007). İletişim Etiği Sorunlar ve Sorumluluklar, Ankara: Gazi Üniversitesi İletişim Fakültesi Baskıevi.

http://www.sanalbasin.com/haber-siteleri, Erişim Tarihi: 18.02.2016.

http://www.connectedvivaki.com/hangi-site-ne-kadar-tiklaniyor-ocak-ayi-gemiusverileri-01-2014/ Erişim Tarihi: 18.02.2016. 